Revista Brasileira de Higiene e Sanidade Animal

Brazilian Journal of Hygiene and Animal Sanity

ISSN: 1981-2965

\title{
Bacterial contamination in curd cheese sold in the northeastern region of South America
}

\author{
Contaminação bacteriana em queijo coalhado vendido na região Nordeste da América do Sul
}

\section{Tamiles Barreto de Deus ${ }^{(1)}$, Ludmilla Santana Soares Barros ${ }^{(1)}$, Ricardo Mendes da Silva ${ }^{(2)}$, Wanessa Karine da Silva Lima ${ }^{(1)}$, Danuza das Virgens Lima ${ }^{(1)}$}

\begin{abstract}
The present study evaluated the microbiological and sanitary quality of curd cheese sold on the beaches of the Itaparica Island, Brazil, and verified whether a correlation exists between the commercialization conditions and the microbiological data. The research was performed between December 2015 and March 2017. Sixty samples of rennet-containing cheese were collected to estimate the populations of mesophylls, psychrotrophic microorganisms, mold and yeast, Staphylococcus aureus, total coliforms, and Escherichia coli. An observational analysis was performed during the collection, using a checklist to verify the sellers' sanitary conditions and cheese marketing. A high nonconformity index was registered regarding aspects in the checklist. In the microbiological analyses, the number of mesophylls in raw and roasted samples ranged 7,88-14,82 $\log \mathrm{CFU} / \mathrm{mL}$, and those of psychrotrophs ranged 2,80-3,84 $\log \mathrm{CFU} / \mathrm{mL}$. Meanwhile, mold and yeast levels in the samples ranged 8,06-5,54 $\log \mathrm{CFU} / \mathrm{mL}$, S. aureus was detected at levels of 3,24-4,94 $\log \mathrm{CFU} / \mathrm{mL}$, and the total coliform counts ranged 4,48-7,18 $\log \mathrm{CFU} / \mathrm{mL}$. The number of E. coli specimens ranged 2,96-5,75 $\log \mathrm{CFU} / \mathrm{mL}$. Microbial insecurity was noted for commercialized curd cheese, and the need for intervention was indicated.
\end{abstract}

Index terms: Sanitary conditions; Food safety; Informal trade; Cheese

Author for correspondence. E.Mail: *: barros@ufrb.edu.br

Recebido em: 10.02.2017. Aceito 30.09.2017

(1) Universidade Federal do Recôncavo da Bahia- Centro de Ciências Agrárias, Ambientais e Biológicas. Rua Rui Barbosa, 710 - Campus Universitário, 44380-000, Cruz das Almas/BA Brazil. tamynutri24@yahoo.com, barros@ufrb.edu.br, ricardomendes@ufrb.edu.br, wanessa_karine@hotmail.com,danuza_lima22@hotmail.com

(2) Universidade Federal do Recôncavo da Bahia- Centro de Ciências da Saúde. Santo Antônio de Jesus - BA - Brazil

http://dx.doi.org/10.5935/1981-2965.20170025

\section{Introduction}

Street-vended food is highly popular in many countries, feeding several people and providing a decent income for families ${ }^{1}$; however, it is a major cause of foodtransmitted diseases (FTDs) and various health issues ${ }^{2}$.

Traditional street-vended food could represent a major risk to public health, due to the unsanitary and unhygienic conditions, including poor infrastructure, improper storage temperature, and poor hygiene among the handlers during commercialization ${ }^{3}$. Curd cheese is one of the most commercialized and consumed foods even though it is homemade and the absence of microbiological contamination cannot be ensured; however, it has social and economic relevance, especially for small-sized farms ${ }^{4}$. Informal food vending is a common practice characterized by high microbiological risk, carrying serious health liabilities for consumers 5 . Moreover, beaches represent the preferred commercialization site, resulting in high contamination rates 6. Considering the informal sale of milk and its derivatives, several studies previously 
identified the main pathogenic microorganisms, namely Staphylococcus aureus, Salmonella spp., Listeria monocytogenes and Escherichia coli ${ }^{7,8,9,10}$.

curd cheese is valuable because the consumption of contaminated food may cause FTDs; thus, representing a public health problem. The present study evaluated the microbiological and sanitary quality of curd cheese sold on the beaches of the Itaparica Island and verified whether a relationship exists between the commercialization conditions and the reported microbiological data.

\section{Materials and Methods}

The study was undertaken at 10 beaches on the Itaparica Island. The following beaches were chosen at random: Praia de Mar Grande, Ponta de Areia, Conceição, Caixa Prego, Barra do Gil, Aratuba, Coroa, Barra do Pote, Barra Grande and Berlinque.

Sixty samples of curd cheese were collected. Three curd cheese vendors, chosen at random, provided three raw and three roasted pieces of cheese. Samples were collected in the daytime on Saturdays and Sundays between December 2015 and March 2016, during holidays, when majority of food makers and vendors were available.

Samples were collected aseptically, transported in an isothermal container with ice, and maintained under refrigeration until microbiological analyses were conducted at the Microbiology and Animal Parasitology laboratory of the Universidade Federal do Recôncavo da Bahia (UFRB), Brazil.

An observational analysis was performed at the time of sample harvesting using a checklist based on Decree 216/2004 and Normative Instruction 30/2001, which included questions on the handlers' hygiene and sanitary habits and the commercialization and storage of cheese. The temperature of cheese was registered immediately after retrieving the samples to verify compliance with the legislation ${ }^{11,12}$. The microbiological analyses comprised the total counts of psychrotrophic microorganisms, mesophylls, mold and yeast, $S$. aureus, total coliforms and

\author{
Knowledge concerning the \\ microbiological quality of commercialized
}

E. coli. The pour plate technique was employed for the microbiological analyses of psychrotrophic microorganisms and mesophylls, with plate count agar used as the culture medium. Samples ( $25 \mathrm{mg}$ in total) were obtained from several sites of each specimen and placed in 225-mL sterile flasks containing $0.1 \%$ peptonized water, and $1 \mathrm{~mL}$ of each dilution was transferred to a Petri plate with 25 $\mathrm{mL}$ of previously heated agar at $43-45^{\circ} \mathrm{C}$.

After homogenization and solidification, plates were incubated in a buffer at $7{ }^{\circ} \mathrm{C}$ for 10 days or at $35{ }^{\circ} \mathrm{C}$ for $48 \mathrm{~h}$ for psychrotrophic microorganisms and mesophylls, respectively. Colonies were counted using a colony counter. The average colony number on each plate was multiplied by the corresponding dilution factor, and the result was presented as $\log \mathrm{UFC} / \mathrm{mL}$.

The spread plate method was employed to calculate the mold and yeast counts in Sabouraud dextrose agar medium. Plates containing $25 \mathrm{~mL}$ of culture medium were prepared and inoculated with $0.1 \mathrm{~mL}$ of each dilution on the medium surface, and the inoculum was spread carefully. Plates were then incubated in BOD buffer at $24^{\circ} \mathrm{C}$ for 48 $72 \mathrm{~h}^{13}$.

Coliforms were counted using Chromocult ${ }^{\circledR}$ coliforms agar, following the manufacturer's instructions. Colonies were counted using a colony counter, in particular, dark blue to violet colonies were classified as Escherichia coli, and salmon red colored colonies as other coliforms.

S.aureus levels were analyzed using a rapid method with Petrifilm ${ }^{\mathrm{TM}}$ plates $(3 \mathrm{M}$ Company), following the manufacturer's instructions. Red-violet colonies were identified as $S$. aureus.

Statistical analysis was performed using SPSS 17, and descriptive analysis comprised means and standard deviations for quantitative variables and proportions for qualitative variables. 
Student's $t$-test was employed for independent samples to compare the microorganism levels between raw and roasted cheese. $p \leq 0.05$ denoted statistical significance.

Checklist variables according to mesophyll, psychrotroph, mold and yeast, $S$. aureus, total coliform, and E. coli levels in raw and roasted curd cheese were analyzed using Student's $t$-test.

The relationship between temperature and microorganism levels was assessed using
Pearson's correlation analysis. $p \leq 0.01$ denoted statistical significance.

\section{Results}

\section{The workers}

Table 1 shows the results of observational analysis of food handlers' hygiene, which is important for preventing food contamination. This analysis revealed a low index for personal care, as 90, 13.3, and 53.3\% of handlers had long and dirty fingernails, used adornments, and wore a beard, respectively.

Table I. Results for items assessed using the checklist related to the hygiene and sanitary habits of the handlers and the manner of curd cheese commercialization on the beaches of the Itaparica Island, BA, Brazil, 2016

\begin{tabular}{ccc}
\hline Assessed items referring to handlers & \% noncompliant & \% compliant \\
\hline Whort and clean fingernails lacking nail polish? & 90 & 10 \\
Were adornments used? & 13.3 & 86.7 \\
Did males have a beard or mustache? & 53.3 & 46.7 \\
Was the tiller distinct from the food handler? & 100 & 100 \\
Did handlers wash their hands prior to food preparation? & 100 \\
Did they wear uniforms? & 100 \\
Was the white uniform clean? & 100 \\
Did they wear closed shoes? & 100 \\
Did they wear gloves during food preparation? & 100 \\
Assessed commercialization items & 100 \\
Were there any eyelets? & \\
Was there any surface slime? & 100 \\
Did the cheese smell? & \\
Was the storage area clean? &
\end{tabular}

\section{Microbiological profile of raw and roasted curd cheese}

Table 2 presents the results of microbiological analyses of raw and roasted curd cheese. A comparison of the average microbial content of cheese samples using Student's $t$-test revealed that the levels of mesophylls, mold, yeast, $S$. aureus, total coliforms, and E. coli were lower for roasted cheese $(p<0.5)$, indicating high levels of contamination of raw cheese.
The levels of mesophyll microorganisms in raw and roasted cheese ranged 7.88-14.82 log $\mathrm{CFU} / \mathrm{g}$. When compared to the mesophyll microorganisms, psychrotrophic microorganisms (Table 2) were less prevalent in raw (3.64 log CFU/g) and roasted (2.80 log $\mathrm{CFU} / \mathrm{g}$ ) cheese. Curd cheese samples displayed high mold and yeast levels, averaging $8.06 \mathrm{log}$ $\mathrm{CFU} / \mathrm{g}$ in raw cheese and $5.54 \mathrm{log} \mathrm{CFU} / \mathrm{g}$ in roasted cheese (Table 2). 
Table II. Results for populations of microorganisms (log CFU/g) in samples of curd cheese sold on the beaches of the Itaparica Island, BA, Brazil, 2016

\begin{tabular}{cccccccccc}
\hline & \multicolumn{3}{c}{$\begin{array}{c}\text { Raw cheese } \\
\text { log CFU/g }\end{array}$} & \multicolumn{4}{c}{$\begin{array}{c}\text { Roasted cheese } \\
\text { log CFU/g }\end{array}$} & $\begin{array}{c}\text { RDC } \\
\mathbf{1 2 / 2 0 0 1}\end{array}$ \\
\hline Microorganisms & Min & Max & Av & SD & Min & Max & Av & SD & CRU \\
Mesophylls & 6.33 & 17.55 & 14.82 & 2.92 & 5.47 & 10.30 & 7.88 & $<1$ & NA \\
Psychrotrophs & $<1$ & 8.20 & 3.64 & 1.78 & $<1$ & 6.46 & 2.80 & 1.58 & NA \\
Mold & $<1$ & 12.13 & 8.06 & 2.16 & $<1$ & 9.11 & 5.54 & 2.18 & NA \\
Staphylococcus & $<1$ & 10.41 & 4.94 & 2.62 & $<1$ & 5.41 & 3.24 & 1.57 & 2.7 \\
$\quad \begin{array}{c}\text { aureus } \\
\text { Total coliforms }\end{array}$ & 4.33 & 11.02 & 7.18 & 1.89 & $<1$ & 6.79 & 4.48 & 1.67 & NA \\
Escherichia Coli & $<1$ & 10.14 & 5.75 & 2.82 & $<1$ & 5.90 & 2.96 & 1.87 & 2.7 \\
& & & & & & & & &
\end{tabular}

Av: Average; Min: Minimum; MAX: Maximum; SD: Standard Deviation; NA: not applicable.

\section{Relationship between temperature and microorganism levels}

Table 3 reveals the negative correlations between the temperature of roasted cheese and the levels of mesophylls, S. aureus, and E. coli; in particular, higher roasting temperatures were associated with lower microorganism levels. Although the initial population counts decreased, the samples exhibited minimum, mean, and maximum temperatures of $44.0,58.2$, and $72.4^{\circ} \mathrm{C}$, respectively.

Table III. Pearson's correlation analysis between temperature and microorganism levels in raw

and roasted curd cheese commercialized on the beaches of the Itaparica Island, BA, Brazil 2016

\begin{tabular}{ccc}
\hline Microorganisms & $\begin{array}{c}\text { Correlation coefficient for roasted } \\
\text { cheese }\end{array}$ & $\begin{array}{c}\text { Correlation coefficient for raw } \\
\text { cheese }\end{array}$ \\
Mesophylls & $-0.64^{*}$ & 0.20 \\
Psychrotrophs & 0.13 & 0.07 \\
Mold & -0.29 & -0.29 \\
Staphylococcus aureus & $-0.39^{*}$ & -0.18 \\
Total coliforms & -0.31 \\
Escherichia coli & $-0.58^{*}$ \\
\hline
\end{tabular}

statistically significant $(p<0.01)$

\section{Discussion}

\section{The Workers}

Furlaneto-Maia et al. ${ }^{14}$ and Chukuezi 15 also reported high noncompliance rates among the food handlers concerning their body care. Inadequacy concerning these factors contributes to increased transmission risks of pathogenic agents via commercialized food.

All food vendors were observed to handle money and food simultaneously, without washing their hands, jeopardizing proper food handling (Table 1). Cortese et al. ${ }^{16}$ also reported low efficiency for this factor, confirming global studies regarding the lack of hygiene among the food 
handlers. Microorganisms are present on the hands in substantial amount, and they are extremely difficult to eliminate. Thus, proper hygiene is vital for preventing FTDs.

When the food handlers were examined for their uniforms (Table 1), all were found without gloves, headwear, uniforms, and closed shoes; this was contrary to RDC 216, which insists that all food handlers should wear clean and good uniforms compatible with their activities.

The commercialized cheese had a wide range of hole sizes (Table 1), which may be related to poor conditions during manufacturing. Lactose-fermenting bacteria also produce $\mathrm{CO}_{2}$, and they may give rise to microcavities known as cheese eyelets ${ }^{17}$.

No commercialized cheese samples had pungent odors or surface slime, and no inadequacies were registered (Table 1). Meanwhile, Franco \& Landgraf ${ }^{18}$ found that these items are highly efficient concerning the aspects of hygiene and food safety.

All commercialized cheese was stored at room temperature even though the technical rules on the identity and quality of curd cheese stipulate that cheese should be stored at a temperature not exceeding $12^{\circ} \mathrm{C}$ during conservation and commercialization ${ }^{11}$.

Storage data revealed carelessness regarding the containers in which the food was preserved. In fact, $73.3 \%$ (Table 1) of containers did not meet the cleanliness standards. In their study on the hygienic and sanitary conditions of food sellers in Uberaba, Brazil, Souza et al. ${ }^{19}$ reported a lack of compliance regarding the same items.

This lack of compliance may increase the risk of food contamination given the direct link between storage conditions and contamination.

The Table 2 has values which exceeded the values reported by Meneses et al. ${ }^{20}$, who recorded levels of 8.1 and 6.4 $\log \mathrm{CFU} / \mathrm{g}$ for samples of raw and roasted curd cheese, respectively.

High mesophyll levels (Table 2) were also reported by Delamare et al. ${ }^{21}$ in their analysis of homemade Serrano cheese samples manufactured in Brazil. Specifically, the counts of mesophyll bacteria ranged 7.91-9.47 log CFU/g. Although no normative standards exist at present, estimates of such populations are relevant because high levels of mesophyll microorganisms in food indicate deficient hygienic and sanitary conditions.

Although the Brazilian law has not established a limit for psychrotrophic bacteria, Chen et al. ${ }^{22}$ stressed that these microorganisms are responsible for the deterioration of milk and its derivates and that they may alter milk and its derivates by producing enzymes that hydrolyze proteins and lipids, making them inappropriate for consumption.

Although curd cheese is a typical Brazilian product and because mold and yeast can deteriorate the quality of dairy products, Brazilian law has not established the maximum levels for these microorganisms in cheese.

Silva et al. ${ }^{23}$ analyzed the curd cheese manufactured from raw and pasteurized milk in three dairies in the backlands of the state of Alagoas, Brazil, and reported levels of 4.58, 4.66, and 4.86 $\log$ CFU/g, respectively. Perin et al. ${ }^{24}$ analyzed homemade Minas cheese and detected average mold and yeast levels of approximately $5 \log$ CFU/g.

Total coliform levels averaged 7.18 and $4.48 \log$ CFU/g in raw and roasted cheese samples, respectively. Salotti et al. 25 reported that the levels of these microorganisms in food identify the product's sanitary and conservation state; thus, they are indicative of consumers' health risks. Brazilian legislation establishes a limit of $2.7 \log \mathrm{CFU} / \mathrm{g}$ for $E$. coli, whereas the levels in the present 
analysis revealed $5.75 \mathrm{log} \mathrm{CFU} / \mathrm{g}$ in raw cheese and $2.96 \mathrm{log}$ CFU/g in roasted cheese. The presence and high levels of microorganisms were also reported by Oliveira et al. ${ }^{26}$, who assessed the microbiological quality of curd cheese in the municipality of Cabo de Santo Agostinho, PR, Brazil and verified that $80.95 \%$ of samples had bacterial levels exceeding the standard limits.

High levels of E. coli exceeding the standard limits define the product as inappropriate for commercialization and consequently for human consumption due to the fecal contamination ${ }^{27}$.

The examined cheese samples had high $S$. aureus levels, namely $4.94 \mathrm{log}$ CFU/g in raw samples and $3.24 \mathrm{log}$ CFU/g in roasted samples. The results illustrated that $S$. aureus levels in cheese exceeded the standard limits and evidenced serious microbiological liabilities in the commercialized curd cheese.

Tigre \& Borelly ${ }^{28}$ also measured $S$. aureus counts in curd cheese commercialized by the street sellers on the Itapuã Beach in Salvador, BA, Brazil, during morning and afternoon, with the results ranging 4.84-5.73 log CFU/g in the morning and 4.57-6.36 log CFU/g in the afternoon.

S.aureus levels exceeding the standard recommendations (2.7 log CFU/g) may be related to the contamination of prime matter during manufacturing. This fact may be also linked to the handlers because pathogens have common interaction mechanisms with the host and they may be frequently found in skin and mucus ${ }^{29}$. S. aureus levels were high in a study by Machado et al. ${ }^{30}$, who detected levels exceeding $8 \mathrm{log} \mathrm{CFU} / \mathrm{g}$ in curd cheese from several dairies. $S$. aureus produces enterotoxins, which cause food intoxication; thus, they pose a health risk to consumers ${ }^{31}$.

\section{Relationship between temperature and microorganism levels}

According to ABERC ${ }^{32}$, most samples failed to reach the temperature recommended for roasted food, namely a minimum temperature of $74^{\circ} \mathrm{C}$ at the geometric center, or time and temperature combinations such as $65^{\circ} \mathrm{C} / 15 \mathrm{~min}$ or $70^{\circ} \mathrm{C} / 2 \mathrm{~min}$.

In the case of raw cheese, there was a weak negative correlation between $E$. coli levels and temperature (Table 3). Statistical analysis evidenced the opposite correlation. Specialized literature revealed that the best conditions for the growth of these microorganisms are between 30 and $45^{\circ} \mathrm{C}^{18}$.

The temperature of raw cheese exceeded the standard limit ${ }^{11}$, with minimum, mean, and maximum temperatures of $20.6,31.3$, and $35.1^{\circ} \mathrm{C}$, respectively. These findings reveal carelessness regarding the handling procedures, with serious risks for consumers.

Relationship between the hygienic and sanitary conditions in commercialization and microorganism levels

There was no significant difference in the levels of microorganisms related to variables such as storage site and the use of adornments and wearing of a beard by the handlers. Despite these findings, when these aspects are inadequate, they positively affect the food contamination.

On the contrary, a statistically significant correlation $(p<0.05)$ was seen between the total coliform levels and compliance among the handlers regarding clean nails. In fact, total coliform levels were higher among noncompliant handlers. Contamination of food handlers' hands is one of the factors that most strongly contributes to the risk of FTDs.

The microbiological results underscore that data from the checklist 
may be directly related to improper hygiene-sanitary conditions and prove that these aspects are the main causes of contamination.

\section{Conclusion}

High levels of deteriorating and pathogenic microorganisms revealed poor hygienic and sanitary quality in the products analyzed and the need for good practices in food manipulation and commercialization, coupled with efficient monitoring and surveillance by authorities. Based on the established Brazilian microbiological standards, most raw and roasted cheese samples were classified as unfit for human consumption.

\section{References}

1. ABERC (BRAZILIAN ASSOCIATION FOR COMMUNITARIAN MEALS). Handbook for Meal Preparation and Community Service. 9rd ed. São Paulo: ABERC; 2003.

\section{BORGES MF, NASSU RT, PEREIRA} JL, ANDRADE APC, KUAYE AY. Contamination Profile by Staphylococcus and its enterotoxins and monitoring of hygiene conditions in the production of curd cheese. Rural Science 2008; 38:1431-1438.

\section{BORGES MF, NASSU RT, PEREIRA} JL, ANDRADE APC, KUAYE AY. Contamination Profile by Staphylococcus and its enterotoxins and monitoring of hygiene conditions in the production of curd cheese. Rural Science 2008; 38:1431-1438.

4. BRASIL. ANVISA (Brazilian Agency for Sanitary Vigilance). Resolution RDC n. 216, of 15 September 2004. Technical Ruling on Good Practices in Food Services.
5. CDC (Centers for Disease Control and Prevention). Multistate Outbreak of E. coli O157:H7 Infections Associated with Cheese.

https://www.cdc.gov/ecoli/2010/bravofarms-cheese-11-24-10.html: Assessed: January 2017.

6. BRASIL. Ministry of Health. Brazilian Agency for Sanitary Vigilance (ANVISA). Resolution RDC n. 12. January 2001. Technical Ruling on Food microbiological standards. Brazilian Government Gazette, Brasília, 2 January 2001.

7. CHEN L, DANIEL RM, COOLBEAR

T. Detection and impact of protease and lipase activities in milk and milk powders. International Dairy Journal 2003; 13:255-275.

8. CHUKUEZI CO. Food Safety and Hygienic Practices of Street Food Vendors in Owerri, Nigeria. Studies in Sociology of Science 2010; 1:50-57.

9. CORTESE RDM, VEIROS MB, FELDMAN C, CAVALLI SB. Food safety and hygiene practices of vendors during the chain of street food production in Florianopolis, Brazil: A cross-sectional study. Food Control 2016; 62: 178:186.

10. DELAMARE APL, ANDRADE CCP, MANDELLI F, ALMEIDA RC, ECHEVERRIGARAY S. Microbiological, Physico-Chemical and Sensorial Characteristics of Serrano, an Artisanal Brazilian Cheese. Food and Nutrition Sciences 2012; 3:1068-1075.

11. FEGLO $P$, SAKYI $K$. Bacterial contamination of street vending food in Kumasi, Ghana. Journal of Medical and Biomedical Sciences 2012; 1(1): 1-8. 
12. FEITOSA T, BORGES MF, NASSU RT, AZEVEDO EHF, MUNIZ CR. Research on Salmonella sp., Listeria sp. and hygiene-sanitary-indicating microorganisms in cheese manufactured in the state of Rio Grande do Norte. Ciência e Tecnologia Alimentar 2003; 23:162-165.

13. FRANCO BDGM, LANDGRAF M. Microbiology of food. São Paulo: Atheneu, 2008.

14. GUIMARÃES AG, CARDOSO RCV, AZEVÊDO PF, MENESES RB. Profile of antimicrobial susceptibility profile of bacteria isolated from curd cheese. Revista do Instituto Adolfo Lutz 2012; 71:25965 .

15. FREITAS MFL, LUZ IS, PINHEIRO JÚNIOR WJ, DUARTE DAM, VASCONCELOS AMM, RIBEIRO AR, MOTA RA, BALBINO TCL, STAMFORD TLM. Detection of toxigenic genes in Staphylococcus spp. samples isolated from curd cheese. Ciência e Tecnologia Alimentar 2009; 29:375-379.

16. FURLANETO MAIA L, OLIVEIRA MT, OLIVEIRA AF. Hygiene-sanitary conditions, microbiological quality and antimicrobial susceptibility test in strains isolated from sandwiches sold by street vendors. Revista do Instituto Adolfo Lutz 2010; 69:489-496.

17. HEIKENS E, FLEER A, PAAUW A, FLORIJN A, FLUIT AC. Comparison of genotypic and phenotypic methods for species-level identification of clinical isolates of coagulase-negative staphylococci.) Journal Clinical Microbiology 2005; 43:2286-2290.

18. LUCCA A, TORRES EAFS. Hygiene conditions of the hot dog sold on the streets. Revista Saúde Pública 2002; 36:350-352.
19. MACHADO TF, BORGES MF, PORTO BC, SOUSA CT, OLIVEIRA FEM. Interference of autochthone microbiota of curd cheese on positive Staphylococcus coagulase. Revista Ciências Agronômicas 2011; 42: 337-341.

20. MENESES RB, CARDOSO RCV, GUIMARÃES AG, GÓES JAW, SILVA AS, ARGOLO SV. Curd cheese trade on the beaches of Salvador, Bahia: child labor and food safety. Revista Nutrição 2012; 25: 381-392.

21. OLIVEIRA KA, NETO JE, PAIVA JE, MELO LEH. Microbiological quality of curd cheese commercialized in the municipality of Santo Agostinho, Pernambuco, Brasil. Arquivos do Instituto Biológico 2010; 77: 435-440.

22. ORDOÑEZ, JA. Food Technology. São Paulo: Artmed, 2005.

23. OSTYN A, BUYSER ML, GUILLIER F, GROULT J, FÉLIX B, SALAH S, DELMAS G, HENNEKINNE JA. First evidence of a food poisoning outbreak due to staphylococcal enterotoxin type $E$, France, 2009. Eurosurveillance 2010; $15: 13$.

24. PERIN LM, BELLO BD, BELVISO S, ZEPPA G, CARVALHO AF, NERO LA. Microbiota of Minas cheese as influenced by the nisin producer Lactococcuslactis subsp. lactis GLc05. International Journal of Food Microbiology 2015; 2:159-167.

25. RAR, OKAZAKI MM. Handbook on methods of microbiological analysis of food. 3rd ed. São Paulo: Varela; 2007.

26. RODRIGUES LK, GOMES JP, CONCEIÇÃO RCS, BROD CS, CARVALHAL JB, ALEIXO JAB. Hygiene and sanitary conditions of food 
vendors in Pelotas-RS. Ciência e Tecnologia Alimentar 2003; 23:447-452.

27. RODRIGUES MJ, BARROS LSS, BARRETO NSE, LIMA DV. Escherichia coli $\mathrm{O} 157$ in curd cheese. African Journal of Agricultural Research 2016; 11: 407-415.

28. SANTOS ML, BARROS LSS, SILVA IMM, ANDRADE MVS, LIMA DV. Prevalence of pathogens and microbiological quality of milk marketed in the region of the Recôncavo from Bahia, Brazil. International Journal of Environmental \& Agriculture Research 2016; 2:75-81.

29. SOUZA GC, SANTOS CTB, ANDRADE AA, ALVES L. Street food: Hygiene-sanitary conditions of food handlers. Science and Communitarian Health 2015; 20: 2329-2338.

30. SILVA MCD, RAMOS ACS, MORENO I, MORAES JO. Influence of manufacture procedures on the physical, chemical, sensorial and microbiological characteristics of curd cheese. Revista do Instituto Adolfo Lutz 2010; 69: 214-21.

31. SILVA N, JUNQUEIRA VCA, SILVEIRA NFA, TANIWAKI MH, SANTOS RFS, GOMES SALOTTI BM, CARVALHO ACFB, AMARAL LA, VIDAL-MARTINS AMC, CORTEZ AL. Microbiological quality of fresh Minas cheese commercialized in the municipality of Jaboticabal, SP, Brasil. Arquivos do Instituto Biológico 2006; 73: 171-175.

32. SILVA MP, CAVALLI DR, OLIVEIRA TCRM. Assessment of standard coliforms at $45^{\circ} \mathrm{C}$ and comparison of efficiency of multiple tube and petrifilmec techniques to detect total coliforms and Escherichia coli in food. Ciência e Tecnologia Alimentar 2006; 26:352-359.
33. TIGRE DM, BORELLY MAN. Research on positive Staphylococcus coagulase in curd cheese samples sold by street vendors on the beaches of Itapuã (Salvador-BA). Review of Medical and Biological Sciences 2011; 10:162-166. 